\title{
Effects of Salvadora persica Extract on the Bacterial Population in Single-species Biofilm
}

(Kesan Ekstrak Salvadora persica terhadap Populasi Bakteria dalam Biofilem Spesies-tunggal)

\author{
NORDIN FATIN-MAJdINA, HAJI ABD RAHIM ZUBAIDAH*, ABD RAZAK MONICA@MUNIRAH \& MOHD BAKRI MARINA
}

\section{ABSTRACT}

The effect of S. persica extract on the population of bacteria in single-species biofilm was investigated. An artificial mouth (NAM) system was used for the development of biofilm. In one experiment, aqueous extract of S. persica at subMIC concentration $(5 \mathrm{mg} / \mathrm{mL})$ was first pumped into the NAM system to treat the experimental pellicle on glass beads before inoculating it with the bacteria (Strep. mitis, Strep. mutans and Strep. sanguinis). This would resemble using the aqueous extract of $\mathrm{S}$. persica before meals. In another experiment, the aqueous extract of $\mathrm{S}$. persica was pumped into the NAM system after the bacterial inoculation and this would resemble using it after meals. In both experiments, $24 \mathrm{~h}$ biofilms were allowed to form. The bacterial population of the biofilms was determined and expressed as colony forming unit per $m L\left(c f u m L^{-1}\right)$. For negative control, sterilized distilled water was used whereas for positive control, commercial Listerine. It was found that the population of Strep. mitis, Strep. mutans and Strep. sanguinis in the respective biofilms for both experiments involving treatment with S. persica extract or Listerine was significantly reduced by more than $70 \%(\mathrm{p}<0.05)$ when compared with the negative control. Comparing the effect of S. persica with Listerine on the bacterial population of the biofilms when used either before or after meal showed that $\mathrm{S}$. persica is slightly less effective towards $\mathrm{S}$. sanguinis before meal and towards $\mathrm{S}$. mutans after meal $(\mathrm{p}<0.05)$. This study suggests that the efficiency of the antibacterial effect of $\mathrm{S}$. persica is species-related and by its way of usage.

Keywords: Bacterial population; oral biofilm; single-species biofilm; S. persica

\section{ABSTRAK}

Kesan ekstrak S. persica terhadap populasi bakteria dalam biofilem spesis-tunggal dikaji. Model mulut tiruan (NAM) digunakan dalam proses perkembangan biofilem ini. Dalam kajian pertama, ekstrak akueus S. persica pada kepekatan separuh MIC (5 $\mathrm{mg} / \mathrm{mL})$ dipam masuk ke dalam sistem NAM bagi merawat pelikel eksperimen yang terbentuk pada manik kaca sebelum diinokulasi dengan bakteria terpilih (Strep. mitis, Strep. mutans dan Strep. sanguinis). Langkah ini menyerupai penggunaan ekstrak akueus S. persica sebelum makan. Dalam kajian kedua, ekstrak akueus S. persica dipam masuk ke dalam sistem NAM selepas inokulasi bakteria terpilih dan langkah ini menyerupai penggunaan ekstrak selepas makan. Pembentukan biofilem dalam kedua-dua kajian dibiarkan selama 24 jam. Populasi bakteria yang terbentuk pada biofilem dikenal pasti dan dibentangkan dalam unit koloni per $m L$ ( $c f u L^{-1}$ ). Air suling steril digunakan sebagai kawalan negatif dan Listerine komersial sebagai kawalan positif. Keputusan bagi kedua-dua kajian menunjukkan Strep. mitis, Strep. mutans dan Strep. sanguinis dalam biofilem masing-masing melibatkan rawatan dengan ekstrak S. persica atau Listerine dibandingkan dengan kawalan negatif berupaya mengurangkan perlekatan bakteria secara signifikan sehingga lebih daripada $70 \%$ ( $<<0.05)$. Perbandingan kesan S. persica dengan Listerine terhadap populasi bakteria dalam biofilem yang digunakan sebelum dan selepas makan menunjukkan sedikit perbezaan keberkesanan $\mathrm{S}$. persica terhadap Strep. sanguinis sebelum makan dan Strep. mutans selepas makan ( $<<0.05)$. Kajian ini menunjukkan keberkesanan kesan antibakteria S. persica adalah berkait dengan spesies dan cara penggunaannya.

Kata kunci: Biofilem mulut; biofilem spesies-tunggal; populasi bakteria; S. persica

\section{INTRODUCTION}

Dental plaque (oral biofilm) formation is a natural process occurring on tooth surfaces in the oral cavity. The process involved the attachment and proliferation of bacteria on the tooth surface. Bacteria initially need to adhere to an acquired pellicle on a tooth surface and subsequently produce extracellular materials. The pioneering bacteria are known as early colonizers. The acquired pellicle whose formation involved the deposition of the components in saliva as it flows over the tooth surfaces of teeth plays a crucial role in plaque formation. The pellicle provides binding receptors for the early colonizers to colonize the tooth surfaces (Fathilah 2011; Nield-Gehrig 2003). A suitable environment is then created and provides favorable sites for the attachment of secondary colonizers. Streptococci are the predominant organisms in the oral cavity during the early stage of plaque formation (Hasnor et al. 2008). 
Untreated plaque accumulating on tooth surfaces may lead to dental caries. Thus an attempt to control plaque accumulation or protect against its deleterious effects has been the main focus of the prevention of plaque-related dental diseases. Indeed, people in most parts of the world are attempting to maintain dental health by regular removal of dental plaque using a variety of mechanical cleaning methods such as brushing, flossing and gargling using mouth rinse (Addy et al. 1992). It is believed that these activities can prevent or limit the bacterial adhesion and the subsequent growth of dental plaque on the tooth surface.

A number of natural products have been evaluated for their potential application in the prevention and treatment of oral diseases. Salvadora persica (S.persica) is one that has been considered a medicinal plant and whose roots and sticks are used widely for cleaning teeth (Al-Bayaty et al. 2010; Al-Mas 2001; Ezoddini-Ardakani 2010). Chemical analysis of $S$. persica has demonstrated the presence of chlorides, salvadourea, organic compound, alkaloids, fluorides, silica, sulfur, tannins, saponins, flavonoids, sterols, sodium chloride and potassium chloride which have a role in oral health maintenance (Goyal et al. 2011; Halawany 2012). It was also reported that $S$. persica has antibacterial, antiplaque and anticaries effects, either being used in natural (chewing stick) or in extracted forms (Al-Mas 2001; Sofrata 2010). There were studies reported that $S$. persica being as efficient as toothbrushes in removing dental plaque. This is attributed to its mechanical cleaning, ability to enhance salivation and biological effect (Goyal et al. 2011; Ma'ayergi et al. 1984). The objective of this paper was to assess the effect of aqueous extract of $S$. persica on the population of selected oral bacteria in single-species biofilm when used before and after meals. The finding may contribute to their application in dental plaque control.

\section{MATERIALS AND METHODS}

\section{PREPARATION OF PLANT EXTRACT}

$S$. persica chewing sticks (miswak) were bought from a local market in Mesir. Aqueous extraction was performed following the method of Al-Mas (2001) and Prachant et al. (2007), where the sticks were cut using a sharp knife and grounded to powder using food blender. $100 \mathrm{~g}$ of the powder was mixed with $2 \mathrm{~L}$ of sterile deionized water and allowed to soak for $48 \mathrm{~h}$ at $25 \pm 1^{\circ} \mathrm{C}$ on a shaking water bath. Following that, the mixture was centrifuged at 10000 rpm for $3 \mathrm{~min}$ and the supernatant collected was filtered using filter paper Whatman No.1. Finally, the extract was freeze-dried overnight and stored at $-20^{\circ} \mathrm{C}$ until further use.

\section{PREPARATION OF BACTERIAL SUSPENSIONS}

Clinical isolates of Strep. mitis and Strep. sanguinis were obtained from the Department of Oral Biology, Faculty of Dentistry, University of Malaya and Strep. mutans ATCC
25175 was bought commercially and stored at $-80^{\circ} \mathrm{C}$ in glycerol. To revive the bacteria, the respective stock was thawed and inoculated into BHI broth (BHI Oxoid). The inoculated broth was then incubated for $18-24 \mathrm{~h}$ at $20^{\circ} \mathrm{C}$. The concentration of the bacterial suspension was standardized to $10^{6}$ cells $/ \mathrm{mL}$ using a spectrophotometer at $550 \mathrm{~nm}$ to an optical density (OD) of about 0.144 (Fathilah 2011).

\section{DETERMINATION OF MINIMAL INHIBITORY CONCENTRATION (MIC)}

The MIC of the $S$. persica extracts was determined based on a microdilution method in 96 multi-well microtiter plates. The dissolved extracts were first diluted to the highest concentration to be tested $(100 \mathrm{mg} / \mathrm{mL}) .100 \mu \mathrm{L}$ of BHI broth was added to each well (1st to 10th well) followed by $100 \mu \mathrm{L}$ of the $S$. persica extract from the 2 nd to the 9th well $(100-0.78 \mathrm{mg} / \mathrm{mL})$. Finally $10 \mu \mathrm{L}$ of bacterial suspension was added to each well. The 1st (BHI broth only) and the 10th (BHI broth+Listerine) wells were used as negative and positive controls, respectively. The plate was then placed in an incubator at $37^{\circ} \mathrm{C}$ for $18-24 \mathrm{~h}$. The lowest concentration at which color change occurred was taken as the MIC value (Al-Bayati \& Sulaiman 2008; AlBayaty et al. 2010). The determination was carried out in triplicate and repeated three times to ensure that the result obtained is reliable.

\section{PREPARATION OF STERILIZED SALIVA}

Whole saliva was collected in ice-chilled tubes from a single donor by expectoration. The saliva was clarified by centrifugation at $1000 \mathrm{rpm}$ for $30 \mathrm{~min}$ and the supernatant was collected and then filter-sterilized through $0.2 \mu \mathrm{m}$ acrodisc syringe filter (Acrodisc Syringe Filters, Pall Corp, USA) into sterile test tubes. This procedure was necessary to ensure that the saliva samples were devoid of microorganisms from the donor (Hasnor et al. 2008).

ASSAY FOR THE BACTERIAL POPULATION IN BIOFILM TREATED WITH S. PERSICA BEFORE AND AFTER MEAL

The development of experimental pellicle and biofilm was carried out in the Nordini's artificial mouth (NAM) model. The model contained glass beads that mimic the surface of the tooth (Hasnor et al. 2008; Rahim et al. 2008). Sterilized saliva was allowed to flow into the NAM model for $2 \mathrm{~min}$ at a flow rate of $0.3 \mathrm{~mL} \mathrm{~min}^{-1}$ to coat the glass beads for the development of the experimental pellicle. This was followed by a flow of sterile distilled water to rinse off the excess saliva on the glass beads.

The experimental pellicle was then treated with the aqueous extract of $S$. persica at sub-MIC $(5 \mathrm{mg} / \mathrm{mL})$ which was allowed to flow into the NAM model at a flow rate of $0.3 \mathrm{~mL} \mathrm{~min}{ }^{-1}$ for $2 \mathrm{~min}$. The bacterial inoculum (Strep. mitis, Strep. sangunis and Strep. mutans) was then pumped into the NAM model separately for $24 \mathrm{~h}$ to form a $24 \mathrm{~h}$ biofilm. This experiment was designed resembling the use of $S$. persica before meal. 
In another study, the respective bacterial inoculum (Strep. mitis, Strep. sanguinis and Strep. mutans) was first allowed to pump into the NAM model separately for $24 \mathrm{~h}$ to form the $24 \mathrm{~h}$ biofilm. Following that, the aqueous extract of $S$. persica $(5 \mathrm{mg} / \mathrm{mL})$ was allowed to flow into the NAM model at a flow rate of $0.3 \mathrm{~mL} \mathrm{~min}^{-1}$ for $2 \mathrm{~min}$, to treat the $24 \mathrm{~h}$ biofilm forming on the surface of the glass beads. This experiment was designed resembling the use of $S$. persica after meal.

For positive control, commercial Listerine and for negative control, sterile distilled water was used in place of the $S$. persica extract. The experiments were carried out in triplicates.

\section{THE HARVESTING OF THE BIOFILM ON GLASS BEADS AND DETERMINATION OF BACTERIAL POPULATION}

Each of the glass beads for the harvesting and determination of bacterial population placed into separate microcentrifuge tube $(1.5 \mathrm{~mL})$ containing $1.0 \mathrm{~mL}$ of Phosphate Buffered Saline (PBS). The tubes were then sonicated for $10 \mathrm{~s}$ and vortexed for $1 \mathrm{~min}$ to dislodge the bacteria in the biofilm on the glass bead and subsequently six serial dilutions were carried out for each of the tubes. T1 was referred to the first tube and T6, the sixth tube of the serial dilutions. $100 \mu \mathrm{L}$ of the serially diluted bacterial suspensions from the T2 to T5 tubes was pipetted out and streaked onto separate brain heart infusion (BHI) agar. The plates were incubated at $37^{\circ} \mathrm{C}$ for $18-24 \mathrm{~h}$ followed by the determination of viable count of bacterial colonies the next day. Plates which gave a CFU number of 30-300 cells were selected and the bacterial population was expressed as colony forming unit per $\mathrm{mL}\left(\mathrm{cfu} \mathrm{mL}^{-1}\right)$ (Hasnor et al. 2008).

\section{DATA ANALYSIS}

The data obtained for the treatment and control group (positive and negative) were compared using ANOVA and Tukey test in post hoc (using SPSS software version 20 ), as the data obtained was normally distributed and $p<0.05$ is considered as statistically significant. Population of the three bacteria in the biofilm was presented in percentage \pm SD based on the following formula;

Calculation of bacteria percentage $=(\mathrm{X} / \mathrm{Y}) \times 100 \%$,

where $\mathrm{X}$ is the mean of bacteria treated with $S$. persica extract (SPE) / Listerine and Y is the mean of bacteria treated with distilled water (negative control).

\section{RESULTS}

\section{DETERMINATION OF MIC}

It was found that the MIC of S persica for the Strep. mitis is $7.64 \pm 2.8 \mathrm{mg} / \mathrm{mL}$, Strep. sanguinis is $8.33 \pm 3.1 \mathrm{mg} / \mathrm{mL}$ and for Strep. mutans, $16.7 \pm 6.3 \mathrm{mg} / \mathrm{mL}$.

\section{BACTERIAL POPULATION IN BIOFILM EXPOSED TO S. PERSICA EXTRACT SIMULATING BEFORE MEAL}

Figure 1 shows the percentage of bacterial population in the biofilms whose experimental pellicle was first treated with the $S$. persica extract before inoculation and those of negative and positive controls. The negative controls for the respective bacteria were referred as $100 \%$ bacterial population. When compared with the negative control, the bacterial population of the S. persica-treated and the

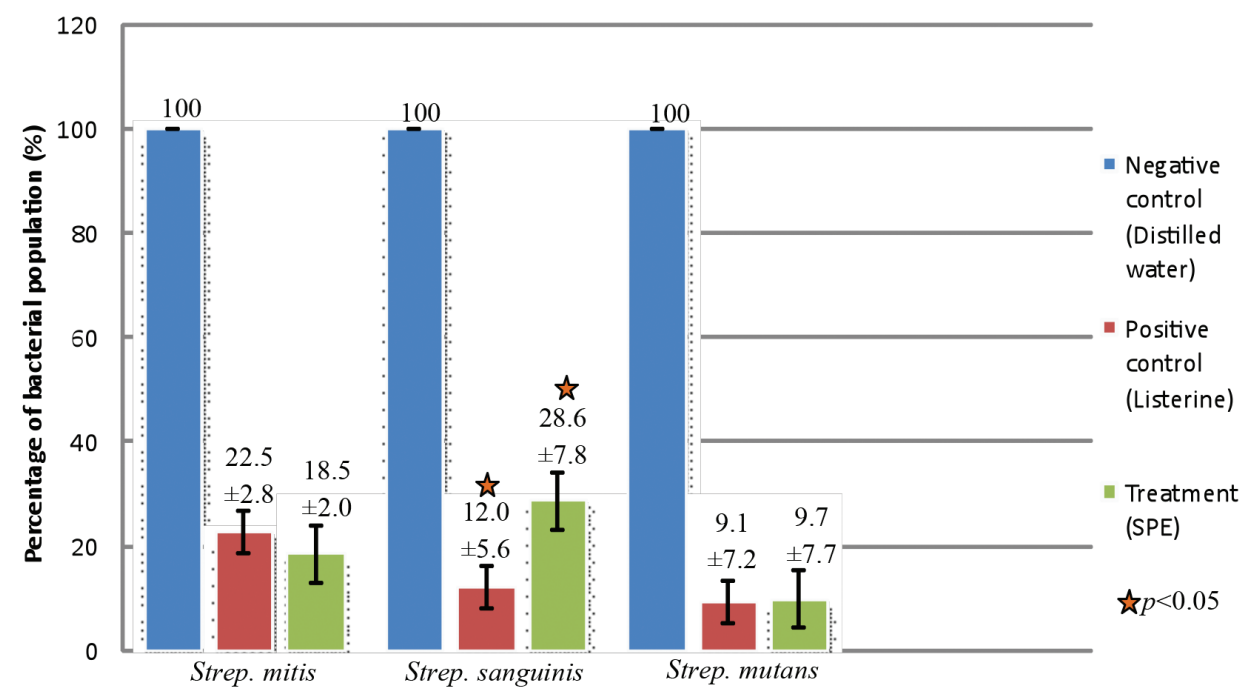

FIGURE 1. Percentage of bacteria population in single-species biofilm. The experimental pellicle was treated first with the $S$. persica extract (SPE) before inoculating with the bacteria. The values were presented as mean \pm Standard Deviation. It was observed that the bacterial population in Listerine-treated compared to S. persica-treated was not significantly different for Strep. mitis and Strep. mutans but, significant for Strep. sanguinis ( $p=0.014)$.

The experiments were carried out in triplicates 
Listerine-treated biofilms was significantly reduced by more than $70 \%(p<0.05)$. It was found that the bacterial population in Listerine-treated compared to $S$. persicatreated was not significantly different for Strep. mitis and Strep. mutans. However, it was observed that S. persica compared with Listerine is slightly less effective towards Strep. sanguinis when its use was simulated as before meal and the difference is statistically significant $(p=0.014)$. This may suggest that the efficiency of the antibacterial effect of Listerine and S. persica towards the oral bacteria is species-dependent.

\section{BACTERIAL POPULATION OF BIOFILM EXPOSED TO S. PERSICA EXTRACT SIMULATING AFTER MEA $L$}

The population of the respective bacteria in a $24 \mathrm{~h}$ biofilm for the negative control, positive control and S. persica for the after meal simulation is shown in Figure 2. It was found that the populations of Strep. mitis and Strep. sanguinis in biofilms of $S$. persica-treated were not statistically different to that of Listerine-treated. However, S. persica compared with Listerine is slightly less effective towards Strep. mutans and the difference is statistically significant $(p=0.031)$. Again, in this simulation it was shown that the effect is species-related.

\section{DISCUSSION}

In this study, Listerine was used as the positive control. Listerine is available commercially and has been claimed to have a good antiplaque activity as it contains thymol as one of its active ingredients (phenolic compound). Thymol is from a plant, the Thymus sp. which has been reported to inhibit the growth of oral bacteria including mutans streptococci (Brecx et al. 1990; Shapiro \& Guggenheim 1995; Shapiro et al. 1994). Since this study also involve the use of plant extract, it is appropriate to use Listerine as the positive control.

There are two aspects of the potential use of S.persica in the maintenance of dental health being emphasized in this study. The first aspect was to determine the effect of $S$. persica on the bacterial population of biofilm in which the experimental pellicle was pretreated before inoculation. It reflects the use of $S$. persica in the control of plaque development immediately after tooth brushing or before meal. S. persica is one of the plants that have been used in oral health care by Prophet Mohammad S.A.W. (Bos 1993). Strep. mitis and Strep. sanguinis were among the early colonizers of oral biofilm whereas Strep. mutans was among the secondary colonizers of oral biofilm and has a role in the aetiology of dental caries.

Experimental pellicle represents the first stage of plaque development on the tooth surface. In the experiment simulating before meal, the properties of the receptors on the experimental pellicle may be altered by $S$. persica, making it less receptive to the adhesins on the bacterial cell walls causing less bacteria to adhere. This may explain the reduction in the bacterial population in the treated biofilms compared with the negative control. The most hydrophobic streptococci are the Strep. sanguinis allowing the Strep. sanguinis to adhere strongly to saliva-coated surfaces or experimental pellicle (Fathilah 2011). This may also explain why the adherence of Strep. sanguinis in the treated biofilms simulating before meal as reflected by the bacterial population is higher compared to Strep. mitis and Strep. mutans.

The second aspect of this study where the biofilm that was allowed to develop first before treating with $S$.

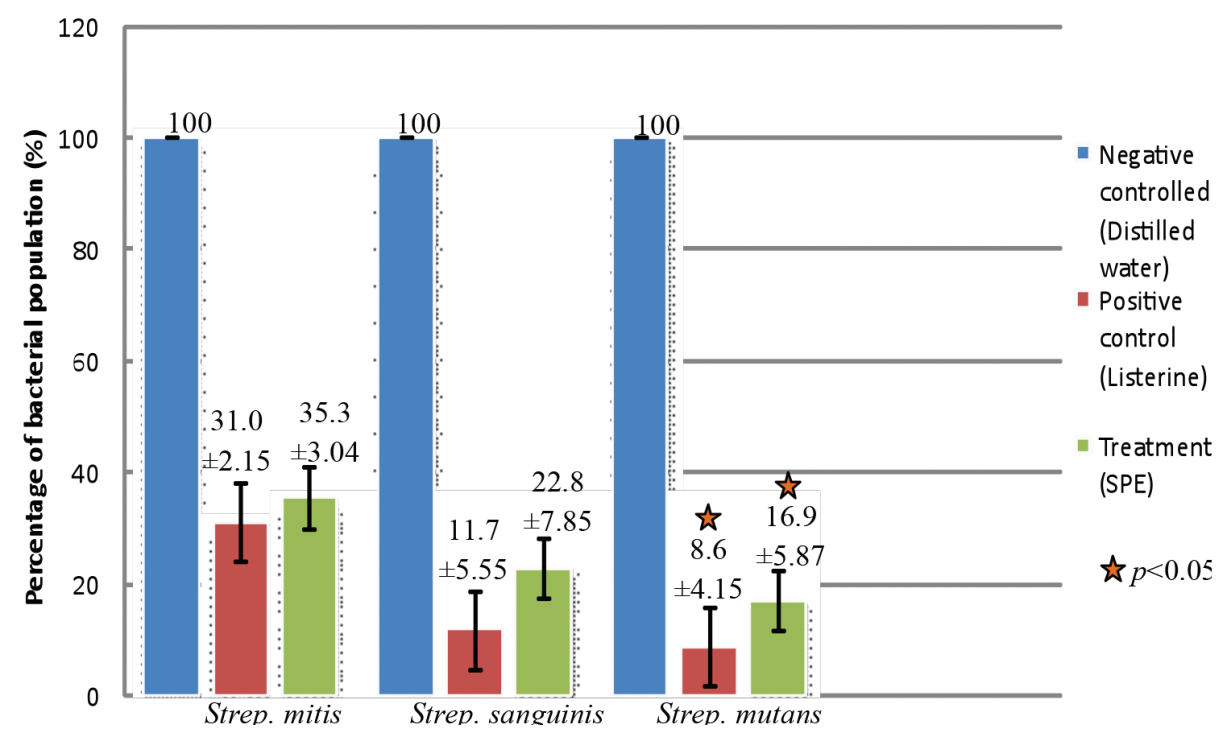

FIGURE 2. Percentage of bacteria population in single-species biofilm. The biofilm formed after the bacteria inoculation was treated with $S$. persica extract (SPE). The values were presented as mean \pm Standard Deviation. It was found that the populations of Strep.mitis and Strep. sanguinis in biofilms of S. persica-treated were not statistically different to that of Listerine-treated, except for Strep. mutans $(p=0.031)$. The experiments were carried out in triplicates 
persica represents its effect on the bacterial population in biofilm simulating $S$. persica being used after meal. It was observed that the retention of Strep. mutans and Strep. Sanguinis were less compared to Strep. mitis in both the $S$. persica- and Listerine-treated biofilms. The results obtained in this study suggest that $S$. persica extract is able to preserve the ecological balance of the biofilms which is almost comparable to Listerine. Ecological balance is important for a healthy oral environment as some of the oral microbes are harmful while some are normal and beneficial in preventing diseases. Killing all the oral bacteria may cause imbalance of the oral ecology which may promote the pathogenic bacteria to predominate.

\section{CONCLUSION}

In this study, it was shown that $S$. persica aqueous extract has significant effect in reducing the bacterial population in biofilm developed in a dynamic environment and it is comparable to that of Listerine both when used before and after meals.

\section{ACKNOWLEDGEMENTS}

This article is a part of author's Master (Fatin-Majdina Nordin) research entitles: A study from Islamic and dentistry perspectives on the use of chewing stick $(S$. persica) in oral health care. This research has been funded by Posgraduate Research Fund (PV134-2012A, University of Malaya.

\section{REFERENCES}

Addy, M., Slayne, M.A. \& Wade. W.G. 1992. The formation and control of dental plaque-an overview. Journal of Applied Bacteriology 73: 269-278.

Al-Bayati, Firas, A. \& Khudir D. Sulaiman. 2008. In vitro antimicrobial activity of Salvadora persica L. extracts against some isolated oral pathogens in Iraq. Turkish Journal of Biology 32: 57-62.

Al-Bayaty, F.H, Aiman Hamad Al-Koubaisi, Nidhal Abdul Wahid Ali \& Mahmood Ameen Abdulla. 2010. Effect of mouth wash extracted form Salvadora persica (Miswak) on dental plaque formation: A clinical trail. Journal of Medicinal Plants Research 4(14): 1446-1454.

Al-Mas, Khalid. 2001. The antimicrobial effects of seven different types of Asia chewing sticks. Odonto-Stomalogie Tropicale Journal 24(96): 17-20.

Al-Mas, Khalid \& Zuhair Al-Zeid. 2004. The immediate antimicrobial effect of a toothbrush and Miswak on cariogenic bacteria: A clinical study. The Journal of Contemporary Dental Practice 5(1): 1-9.

Bos, G. 1993. The Miswak, an aspect of dental care in Islam. Medical History 37: 68-79

Brecx, M., Netuschil, M., Reichert, B. \& Schreil, G. 1990. Efficacy of listerine, meridol and chlorhexidine mouthrinses on plaque, gingivitis and plaque bacteria vitality. Journal of Clinical Periodontol 5: 292-297.

Ezoddini-Ardakani, Fatemeh. 2010. Efficacy of Miswak (Salvadora persica) in preventing dental caries. Health 2(5): 499-503.
Fathilah, A.R. 2011. Piper betle L. and Psidium guajava L. in oral health maiantance. Journal of Medicinal Plants Research 5(2): 156-163.

Goyal, Manoj, Sasmal, D. \& Nagori. B.P. 2011. Salvadora persica (Meswak): Chewing stick for complete oral care. International Journal of Pharmacology 7(4): 440-445.

Halawany, Hassan Suliman. 2012. A review on miswak (Salvadora persica) and its effect on various aspects of oral health. The Saudi Dental Journal 24(2): 63-69.

Hasnor, W.I., Wan Nordini, A.R., Fathilah, M., Md. Yusoff \& Rahim. Z.H.A. 2008. The behaviour of selected oral bacteria in single-and mixed-species biofilms. Journal of Biological Sciences 8(6): 1001-1007.

Ma'ayergi, H.A., Ismail, S.I., Batanouny, K.H. \& Rizk, A.M. 1984. Ecological and phytochemical studies on the Miswak, Salvadora persica L. Qatar University Science Bulletin 4: 37-44.

Nield-Gehrig, Jill S. 2003. Dental Plaque Biofilms. http://www. dentalcarestamford.com/pdf/Denta\%20Plaque\%20Biofilms. pdf. Accessed on 29 January 2013.

Prashant, G.M., Chandu, G.N., Murulikrishna, K.S. \& Shafiulla, M.D. 2007. The effect of mango and neem extract on four organisms causing dental caries: Streptococcus mutans, Streptococcus salivavius, Streptococcus mitis, and Streptococcus sanguis: An in vitro study. Indian Journal of Dental Research 18(4): 148-151.

Rahim, Z.H.A., Fathilah, A.R., Irwan, S.\& Wan Nordini Hasnor. W.I. 2008. An artificial mouth system (NAM Model) for oral biofilm research. Research Journal of Microbiology 3(6): 466-473.

Shapiro, S, Meier, A. \& Guggenheim, B. 1994. The antimicrobial activity of essential oils and essential oil components towards oral bacteria. Oral Microbiol. Immunol. 9: 202-208.

Shapiro, S. \& Guggenheim, B. 1995. The action of thymol on oral bacteria. Oral Microbiol.Immunol. 10(4): 241-246.

Sofrata, A.H. 2010. Salvadora persica (Miswak): An Effective Way of Killing Oral Pathogens. Periodontology Department, Faculty of Dentistry, Karolinska Institute, Stockholm, Sweden.

Nordin Fatin-Majdina, Haji Abd Rahim Zubaidah*

\& Mohd Bakri Marina

Department of Oral Biology

Faculty of Dentistry, University of Malaya

Lembah Pantai

50603 Kuala Lumpur

Malaysia

Abd Razak Monica@Munirah

Jabatan Al-Quran dan Hadith

Akademi Pengajian Islam

University of Malaya

Lembah Pantai

50603 Kuala Lumpur

Malaysia

*Corresponding author; email: zubaidar@um.edu.my

Received: 30 June 2013

Accepted: 25 April 2014 